\title{
Wpływ genetycznych modyfikacji żywności na stan zdrowia jako kwestia społeczna
}

DOI: 10.19195/1643-0328.24.7

Słowa kluczowe: genetyczne modyfikacje żywności, stan zdrowia, kwestia społeczna, GMO w UE i Polsce

\section{Wprowadzenie}

„Kwestia społeczna” to termin używany do opisania poważnych problemów społecznych występujących w skali masowej. Problemy, które urosły do rozmiarów kwestii społecznych, to stany krytyczne widoczne w życiu całych grup społecznych, których efektem są zakłócenia w funkcjonowaniu na poziomie makro. Odnoszą się one do zjawisk wynikających z podstawowych potrzeb oraz ze stopnia ich zaspokojenia ${ }^{1}$.

Konsekwencją procesu identyfikacji kwestii społecznych w węższym rozumieniu są działania wspierające osoby potrzebujące i zwiększające szanse poszkodowanych i ubogich członków społeczeństwa. W szerokim ujęciu proces rozwiązywania kwestii społecznych sprowadza się do opieki nad wszystkimi członkami społeczeństwa, by zmniejszyć zjawiska ryzyka i alienacji jako konsekwencji funkcjonowania społeczeństwa rynkowego ${ }^{2}$.

Celem niniejszego artykułu jest wykazanie, iż problem genetycznych modyfikacji żywności i pasz dotykający nie tylko grup społecznych, a całych społeczeństw, oddziałujący na zdrowie konsumentów, agrosystemy i środowisko naturalne (poziom makro), odnoszący się do procesu zaspokajania podstawowych potrzeb, urasta współcześnie do rangi kwestii społecznej w szerokim ujęciu.

Zarówno wśród badaczy, jak i wśród decydentów politycznych toczy się aktualnie dyskusja dotycząca tego, na ile uprawy genetycznie zmodyfikowane wpisują się w paradygmat i praktykę rozwoju zrównoważonego ${ }^{3}$. Dotychczasowe rozważania w kontekście zrównoważonego rolnictwa odnosiły się głównie do wymiaru ekologicznego, zaniedbu-

\footnotetext{
${ }^{1}$ R. Borowicz, Kwestie społeczne: trudne do rozwiazania czy nierozwiąywalne, Toruń 2008, s. 15.

2 A. Somek, The social question in a transnational context, „LEQS Paper” 39, London 2011, s. 5.

${ }^{3}$ Por. D.E. Ervin, L.L. Glenna, R.A. Jussaume, The theory and practice of genetically engineered crops and agricultural sustainability, „Sustainability” 2011, nr 3, s. 847-874.
} 
jąc aspekty społeczne. Coraz częściej jednak publikowane są badania wskazujące na społeczne skutki upraw genetycznie modyfikowanych. Autorka przewiduje, iż wkrótce badania ukierunkowane na zrównoważony rozwój roślin zdominują obszar badawczy społecznego wymiaru rozwoju zrównoważonego.

Organizmy genetycznie zmodyfikowane (GMO) są definiowane jako organizmy, w których materiał genetyczny został zmieniony w sposób, który nie występuje naturalnie poprzez krzyżowanie lub naturalną rekombinację. GMO mają szerokie zastosowanie, ponieważ są wykorzystywane $\mathrm{w}$ badaniach biologicznych, produkcji leków, medycynie eksperymentalnej i rolnictwie. Używanie technologii genowej w produkcji żywności stało się interesujące ze względu na zwiększone zapotrzebowanie na żywność, a także, w założeniu, na poprawę jej jakości. Dzięki zastosowaniu technologii genowej roślin i zwierząt cele produkcyjne można osiągnąć znacznie szybciej niż w tradycyjny sposób. Konsekwencją tych nowych możliwości są dylematy etyczne i przede wszystkim naukowe, dotyczące ewentualnych negatywnych skutków produkcji żywności genetycznie zmodyfikowanej.

\section{Rodzaje modyfikacji genetycznych żywności i ocena ich skutków społecznych}

Modyfikacje genetyczne najczęściej sprowadzają się do:

- zmiany aktywności genów występujących w danym organizmie;

- wprowadzenia do organizmu jego własnego, dodatkowego genu w celu zwielokrotnienia konkretnej, pożądanej cechy;

- wprowadzenia genu pochodzącego $\mathrm{z}$ organizmu innego gatunku - powstaje wówczas organizm zwany transgenicznym. Odmiany transgeniczne roślin poddawane są najbardziej wnikliwym badaniom w całej historii hodowli roślin. Zgłaszane są obawy co do ich wpływu na agroekosystemy oraz na zdrowie konsumentów ${ }^{4}$.

Najbardziej powszechnymi uprawami genetycznie zmodyfikowanymi są uprawy odporne na herbicydy (HT), następnie uprawy odporne na owady (IR) i uprawy zawierające dwie cechy połączone ${ }^{5}$. Te pierwsze często zapewniają odporność na herbicydy o szerokim spektrum działania zawierające glifosat (na przykład rośliny Roundup Ready ${ }^{\oplus}$ firmy Monsanto i herbicyd Roundup ${ }^{\circledR}$ ). Odporne na owady są uprawy Bt, zmodyfikowane tak, aby zawierały geny bakterii Bacillus thuringiensis (Bt), dzięki czemu rośliny produkują białka toksyczne dla pewnych gatunków owadów.

Częstość występowania i śmiertelność spowodowana chorobami poligenicznymi, takimi jak nadciśnienie tętnicze, choroba wieńcowa, cukrzyca i nowotwory, różnią się zależnie od podatności genetycznej i wpływu środowiska. Szybkie zmiany w diecie

\footnotetext{
${ }^{4}$ M. Kosicka-Gębska, J. Gębski, Problemy rolnictwa światowego, „Zeszyty Naukowe SGGW w Warszawie” 2009, nr 9, s. 65-74.

${ }^{5}$ C. James, Global Status of Commercialized Biotech/GM Crops: 2014, https://www.isaaa.org/resources/ publications/briefs/49/toptenfacts/pdf/B49-Top10Facts-English.pdf (dostęp: 20 grudnia 2017).
} 
i stylu życia mogą wpływać na dziedziczność wariantów fenotypów, które są zależne od nutraceutycznej lub funkcjonalnej suplementacji żywności. Możliwe jest rozpoznanie interakcji żywości z kodem genetycznym ${ }^{6}$.

Mimo iż Światowa Organizacja Zdrowia oświadcza, że produkty GM obecne na rynku międzynarodowym przeszły ocenę ryzyka dokonywaną przez władze krajowe, ogólną ocenę ryzyka GM żywności i upraw, w szczególności w odniesieniu do odżywiania i zdrowia ludzi, deklaracje te nie zostały dotąd zweryfikowane w literaturze naukowej ${ }^{7}$.

Wiedza na temat wpływu społecznego upraw zmodyfikowanych genetycznie pozostaje fragmentaryczna, co przyczynia się do bardzo zindywidualizowanej debaty. Brak systematycznego, szerokiego przeglądu zgromadzonej wiedzy odnośnie do skutków społecznych upraw GM sprawia, że trudno jest wyciągnąć wnioski dotyczące pełnego zakresu i rodzaju zidentyfikowanych skutków społecznych takiej działalności.

Wpływ społeczny definiowany jest jako

konsekwencje dla populacji ludzkiej wszelkich działań publicznych lub prywatnych, które zmieniają sposób, w jaki ludzie żyją, pracują, bawią się, odnoszą się do siebie nawzajem, organizują się, aby zaspokoić potrzeby własne oraz pozostałych członków społeczeństwa. Termin obejmuje również wpływy kulturowe, wiążące się ze zmianami w hierarchii wartości i przekonań, które prowadzą do poznania siebie i społeczeństwa ${ }^{8}$.

Organizacja Narodów Zjednoczonych do spraw Żywienia i Rolnictwa (FAO) opracowała narzędzie oceny zrównoważonego rozwoju systemów żywności i rolnictwa (SAFA) w celu holistycznej oceny zrównoważonego rozwoju w łańcuchu rolnictwo-żywność. Konstruując takie narzędzie, zwrócono uwagę na znaczenie kwestii zrównoważonego rozwoju społecznego w rolnictwie oraz paradygmat rozwoju zrównoważonego w czterech wymiarach: dobrych rządów, integralności środowiskowej, odporności gospodarczej i dobrobytu społecznego 9 .

Badania dotyczące dobrostanu często koncentrują się na zmianach w ekspozycji na toksyny, alergenności i poprawie odżywiania spowodowanych zmianami diety lub poprawą dochodów gospodarstw domowych. Tego rodzaju aspekty zasadniczo muszą być badane na poziomie indywidualnym lub na poziomie gospodarstwa. Wiele badań dotyczących dobrostanu nie opiera się na danych pochodzących z gospodarstw domowych (37 na 48 badań), a zatem dysponujemy ograniczoną liczbą badań stricte empirycznych, co pozwala jedynie na prowadzenie bardziej ogólnej dyskusji, wyrażenie nadziei lub wątpliwości w kontekście potencjalnych skutków upraw genetycznie modyfikowanych na dobrostan. Można stwierdzić, że bardzo niewiele badań zawiera obszerny obraz wpływu społecznego związanego z uprawami genetycznie zmodyfikowanymi

${ }^{6} \mathrm{Ch}$. Verma et al., A review on impacts of genetically modified food on human health, „The Open Nutraceuticals Journal" 2011, nr 4, s. 3-11.

${ }^{7}$ J.A. Magaña-Gómez, A.M. de la Barca, Risk assessment of genetically modified crops for nutrition and health, „Nutr Rev” 2009, nr 67, s. 1-16.

${ }^{8}$ IOCGP, Interorganizational committee on principles and guidelines for social impact assessment, principles and guidelines for social impact assessment in the USA, Impact Assess. Proj. Apprais., 21, 2003, s. 231-250.

${ }^{9}$ FAO, Safa Sustainability Assessment of Food and Agriculture Systems Guidelines Version 3.0, Food and Agriculture Organization, Italy, 2014. 
w rolnictwie. Przeanalizowana literatura (99 prac) została zdominowana przez badanie wpływu ekonomicznego. Co ważne, badania ekonomiczne przedstawiają bardziej pozytywny obraz upraw genetycznie zmodyfikowanych w rolnictwie niż jest to uzasadnione ze względu na szerszy zbiór skutków społecznych ${ }^{10}$.

\section{Badania nad skutkami spożycia organizmów genetycznie modyfikowanych}

Istnieje kilka powodów, dla których rośliny GM stanowią zagrożenie dla ludzi. Pierwszym jest to, że proces inżynierii genetycznej sam tworzy nieprzewidywalne zmiany, niezależnie od tego, który gen jest przenoszony. Co ważne, istnieje możliwość mutacji w okolicach wszczepu ${ }^{11}$.

Jednym ze skutków spożycia GMO są reakcje alergiczne. Pojawiają się, gdy układ immunologiczny identyfikuje coś obcego, odmiennego, a następnie zareaguje. Każdy rodzaj żywności genetycznie modyfikowanej z definicji zawiera coś obcego. Groch zmodyfikowany wywołał reakcję zapalną u myszy. Na tej podstawie badacze uznali, że może powodować śmiertelne reakcje alergiczne u ludzi. Innym przykładem w tym kontekście jest soja zmodyfikowana: oprócz białka tolerującego herbicyd zawiera ona unikalne, nieoczekiwane białko, które prawdopodobnie powstało w wyniku zmian zachodzących podczas procesu inżynierii genetycznej. Zbadano, że to nowe białko było zdolne do wiązania się z przeciwciałami IgE, co sugeruje, że może wywoływać niebezpieczne reakcje alergiczne. Co ciekawe, to rozwiązanie zostało zapożyczone przez inżynierów genetycznych od rolników ekologicznych, którzy zaatakowali rośliny uprawne roztworami zawierającymi naturalne bakterie Bt jako metodę zwalczania owadów. Toksyna ta tworzy dziury w żołądkach owadów i zabija je. Inżynierowie genetyczni wykorzystali gen, który wytwarza toksyny w bakteriach i wprowadzili go do DNA roślin w celu uproszczenia produkcji i zaoszczędzenia czynnika pracy. W rezultacie konsumujemy ten toksyczny pestycyd z każdym kęsem kukurydzy Bt. Badania potwierdzają, że naturalna toksyna Bt nie jest $\mathrm{w}$ pełni niszczona podczas trawienia i reaguje $\mathrm{z}$ ssakami ${ }^{12}$.

Jako pierwsze modyfikacjom genetycznym poddawane były zboża. Stare odmiany pszenicy o nazwie „samopsza” i „płaskurka” nie mają już nic wspólnego ze współczesną pszenicą karłową czy też z powszechnie uważanym za „zdrowszy” orkiszem, który również jest wytwarzany z pszenicy karłowej. Przełomowe dla produkcji pszenicy były lata sześćdziesiąte $\mathrm{XX}$ w. Wówczas to stare odmiany pszenicy uprawiane uprzednio $\mathrm{w}$ warunkach organicznych zaczęły być zastępowane produktem przemysłowym w po-

${ }^{10} \mathrm{~K}$. Fischer et al., Social impacts of GM crops in agriculture: A systematic literature review, „Sustainability" 2015, nr 7, s. 8598-8620.

11 A. Wilson, J.R. Latham, R.A. Steinbrecher, Transformation - induced mutations in transgenic plants: Analysis and biosafety implications, „Biotechnol Genet Eng” 2006, nr 23, s. 105-109.

12 J. Romeis, A. Dutton, F. Bigler, Bacillus thuringiences toxin (Cry $1 \mathrm{Ab}$ ) has no direct on larvae of the green lacewing Chrysoperla carnea (stephens) (Neuroptera: Chrysopidae), „J Insect Physiol” 2004, nr 50, s. 175-183. 
staci pszenicy karłowej: niskiej, masywnej, powstałej na skutek hybrydyzacji oraz modyfikacji genetycznych enzymów i białek. Nowo powstały gatunek daje dziesięciokrotnie większe plony, jest bardziej odporny na suszę, wysokie temperatury i choroby, a co najważniejsze dla jego producentów i przetwórców, zawiera większą ilość glutenu oraz jest odporny na herbicydy ${ }^{13}$. Dlatego też pszenica karłowa zdominowała z czasem inne odmiany i stanowi aktualnie 99\% światowego zasiewu.

Współczesne szczepy pszenicy są tak dalece zmodyfikowane, że nie są już zdolne przetrwać w naturalnym środowisku bez zastosowania pestycydów i herbicydów. Najnowsze badania dowodzą, że glifosat - aktywny składnik herbicydu Roundup firmy Monsanto - zwiększył częstotliwość występowania nietolerancji na gluten oraz choroby trzewnej - celiakii. Spustoszenie, jakie powoduje zastosowanie glifosatu, tłumaczy, dlaczego pszenica była kiedyś lepiej tolerowana - jej produkcja odbywała się bez zastosowania tego herbicydu, dziś jest środkiem najczęściej używanym przy produkcji genetycznie zmodyfikowanych odmian kukurydzy, soi oraz pszenicy. Badania wpływu tej substancji na zdrowie człowieka wykazały, że nawet spożywanie niewielkich ilości prowadzi do poważnych problemów zdrowotnych, takich jak nowotwory i zaburzenia hormonalne. Badania pokazują, że nietolerancja na gluten rośnie wprost proporcjonalnie do wzrostu stosowania glifosatu, ponieważ niszczy on i uszkadza układ pokarmowy, powodując chorobę trzewną, nietolerancję na gluten oraz zespół jelita drażliwego, ponadto uszkadza komórki wątroby, niszczy enzymy oraz florę jelitową ${ }^{14}$.

Oprócz pszenicy dwiema najbardziej powszechnymi uprawami genetycznie modyfikowanymi są kukurydza i soja. W roku 2009 po raz pierwszy przeprowadzona została analiza porównawcza danych dotyczących oddziaływania na krew i organy wewnętrzne szczurów karmionych trzema głównymi zmodyfikowanymi genetycznie odmianami kukurydzy (NK 603, MON 810 i MON 863). Autorzy stwierdzili, że te trzy genetycznie modyfikowane odmiany mają nowe efekty uboczne zależne od płci oraz dawki. Skutki związane były głównie z upośledzoną pracą nerek i wątroby, a zatem organami odtruwającymi, chociaż różniły się w tych trzech modyfikacjach. Inne działania obserwowano również w obrębie serca, nadnerczy, śledziony i układu krwionośnego. Wykazywały one oznaki toksycznego wpływu na wątrobę prawdopodobnie z powodu pestycydów specyficznych dla każdej z odmian kukurydzy GM ${ }^{15}$.

W przeciwieństwie do przedstawionej obawy zgłoszonej przez grupę uczonych inni badacze stwierdzili, że różne ziarna kukurydzy GM są tak samo bezpieczne, jak konwencjonalne ziarna kukurydzy. Najbardziej aktywna grupa naukowców zajmującą się tą kwestią pracowała pod kierownictwem Delaney i od 2007 r. opublikowała znaczącą liczbę artykułów na ten temat.

${ }^{13}$ S. Pietrzyk, K. Błoniarczyk, Żywność genetycznie modyfikowana, „Biotechnologia” 2007, nr 9, s. 34-38.

${ }_{14}$ J.M. Smith, Monsanto's Roundup Triggers Over 40 Plant Diseases and Endangers Human and Animal Health, http://www.livingnaturally.com/PDFDocs/h/HJ2WEEBJAPP58LRWP0A7VX1N09DS7D7D.PDF (dostęp: 11 sierpnia 2015).

15 J.S. de Vendômois et al., A comparison of the effects of three GM corn varieties on mammalian health, „Int J Biol Sci” 2009, nr 5, s. 706-726. 
Podobne badania przeprowadził MacKenzie wraz ze współpracownikami (2007). Trwały one około 90 dni. Do diety szczurów wprowadzono ziarna zmodyfikowanej kukurydzy typu 1507. Odmiana została wyposażona $\mathrm{w}$ dodatkowy gen pochodzący $\mathrm{z}$ bakterii Bacillus thuringiensis, kodujący białko toksyczne dla niektórych owadów. Rośliny transgeniczne wytwarzające białko Bt nie są niszczone przez szkodniki, co pozwala uzyskać większe plony i zredukować ilość lub zrezygnować ze stosowania pestycydów. $\mathrm{W}$ ramach przeprowadzonego badania nie zaobserwowano istotnych różnic $\mathrm{w}$ wartościach odżywczych, objawach klinicznych i neurobehawioralnych, okulistycznych czy patologii klinicznej (hematologia, chemia kliniczna, koagulacja i badanie moczu). Drugiej grupie podawano DAS-59122-7 - transgeniczną odmianę kukurydzy zawierającą specyficzne dla pestycydów białka oraz składnik chwastobójczy glufosynat amonowy. Zdaniem autorów wyniki ich badań wskazują, że zarówno ziarna kukurydzy 1507, jak i 59122 były tak samo odżywcze i bezpieczne dla zdrowia, jak konwencjonalne ziarna kukurydzy ${ }^{16}$.

W badaniach ziaren soi DP-356Ø43-5 przeprowadzanych zarówno na szczurach $(93 \mathrm{dni})^{17}$, jak i na broilerach $(42 \mathrm{dni})^{18}$, nie stwierdzono niekorzystnych skutków dla masy ciała czy wzrostu, nie zaobserwowano negatywnych objawów klinicznych, neurobehawioralnych, patologii klinicznej czy wzmożonej śmiertelności. W związku z tym stwierdzono, że soja genetycznie modyfikowana typu 356Ø43 jest równie odżywcza i bezpieczna dla zdrowia, jak soja niemodyfikowana.

Natomiast badania na myszach (przez 28 dni) dowiodły, że dieta oparta na zmodyfikowanych ziarnach soi typu CP4 EPSPS spowodowała zaburzenia metabolizmu hepatocytów, a w rezultacie wolniejsze procesy metabolizmu ${ }^{19}$. Zarodki genetyczne myszy karmionych soją zmodyfikowaną wykazały również przejściowe zmiany w funkcji DNA $\mathrm{w}$ porównaniu do tych, których rodzice karmieni byli soją uprawianą konwencjonalnie ${ }^{20}$.

Niezależnie jednak od wyników przytoczonych badań wszyscy autorzy zgodnie twierdzili, że konieczne jest podjęcie dalszych naukowych działań w celu budowania zaufania dla oceny i akceptacji genetycznie modyfikowanych upraw i żywności przez społeczność naukową i ogół społeczeństwa.

Istotny w tym kontekście jest artykuł Dona i Arvanitoyannis (2009), którzy zwracają uwagę na możliwość kumulacji toksycznych skutków: wątrobowych, trzustkowych, nerkowych, rozrodczych, tudzież upośledzających procesy hematologiczne, biochemiczne

16 S.A. MacKenzie et al., Thirteen week feeding study with transgenic maize grain containing event DASØ15Ø7-1 in Sprague-Dawley rats, „Food Chem Toxicol” 2007, nr 45, s. 551-562.

${ }^{17}$ L.M. Appenzeller et al., Subchronic feeding study of herbicide-tolerant soybean DP-356Ø43-5 in Sprague-Dawley rats, „Food Chem Toxicol” 2008, nr 46, s. 2201-2213.

${ }^{18} \mathrm{~J}$. McNaughton et al., Comparison of broiler performance when fed diets containing event DP-3Ø5423-1, nontransgenic near-isoline control, or commercial reference soybean meal, hulls, and oil, „Poult Sci” 2008, nr 87, s. 2549-2561.

${ }^{19}$ M. Malatesta et al., A long-term study on female mice fed on a genetically modified soybean: effects on liver ageing, „Histochem Cell Biol” 2008, nr 130, s. 967-977.

20 V.E. Prescott et al., Transgenic expression of bean $r$-amylase inhibitor in peas results in altered structure and immunogenecity, „J Agric Food Chem” 2005, nr 53, s. 176-188. 
i immunologiczne, będących efektem spożywania żywności genetycznie modyfikowanej różnego rodzaju i pochodzenia ${ }^{21}$. Badacze rozpoczęli tym samym dyskusję, która od dawna już toczy się w kontekście innych aspektów bezpieczeństwa żywności - alergenów i dodatków do żywności.

\section{Genetyczne modyfikacje żywności w dokumentach Unii Europejskiej oraz w polskim ustawodawstwie}

Zgodnie z unijnym prawodawstwem dotyczącym modyfikacji genetycznych żaden genetycznie zmodyfikowany organizm, żywność czy pasza nie mogą być wprowadzane do obrotu, zanim nie zostaną zatwierdzone. Ocenę naukową przeprowadza Europejski Urząd ds. Bezpieczeństwa Żywności (EFSA) we współpracy z instytucjami naukowymi państw członkowskich.

W Unii Europejskiej zatwierdzono 58 genetycznie zmodyfikowanych środków spożywczych i pasz. $60 \%$ pasz pochodzi z państw, w których rozpowszechnione są uprawy GMO. W marcu 2015 r. Rada i Parlament uzgodniły zmianę ram prawnych dotyczących GMO, umożliwiającą państwom członkowskim ograniczenie lub zakazanie uprawy zatwierdzonych GMO (dyrektywa 2015/412/UE)22. Rozwiązanie to powinno obejmować również genetycznie zmodyfikowaną żywność i paszę. W tym celu Komisja przedłożyła Parlamentowi Europejskiemu i Radzie wniosek w sprawie zmiany rozporządzenia (WE) nr 1829/2003: proces zatwierdzania GMO pozostanie bez zmian, ale państwa członkowskie uzyskają możliwość decydowania, czy genetycznie zmodyfikowana żywność lub pasza mogą być stosowane na ich terytoriach. Państwa członkowskie nie będą mogły jednak uzasadniać swych decyzji w sposób sprzeczny z oceną ryzyka dla zdrowia ludzi i zwierząt oraz dla środowiska, przeprowadzoną przez Europejski Urząd ds. Bezpieczeństwa Żywności tak, by zachowana została zasada proporcjonalności i niedyskryminacji produktów zagranicznych w stosunku do produktów krajowych. Podobnie jest z GMO przeznaczonymi do uprawy, stanowi o tym dyrektywa 2015/412. Przewidziana jest natomiast procedura na wypadek, gdyby okazało się, że produkt stwarza poważne zagrożenie nieuwzględnione $\mathrm{w}$ trakcie procedury zatwierdzenia. $\mathrm{W}$ takiej sytuacji Komisja i państwa członkowskie mają prawo przyjąć środki nadzwyczajne, które mogą prowadzić do zakazania produktu na całym lub na części terytorium państwa członkowskiego bądź w całej UE. Proponowana zmiana rozporządzenia dotyczącego genetycznie zmodyfikowanej żywności i paszy nie zmieni zasad przeprowadzania oceny naukowej przed zatwierdzeniem GMO.

${ }^{21}$ A. Dona, I.S. Arvanitoyannis, Health risks of genetically modified foods, „Crit Rev Food Sci Nutr” 2009, nr 49, s. 164-175.

22 Parlament Europejski, Rada Europejska, Dyrektywa Parlamentu Europejskiego i Rady (UE) 2015/412 z dnia 11 marca 2015 r. w sprawie zmiany dyrektywy 2001/18/WE w zakresie umożliwienia państwom członkowskim ograniczenia lub zakazu uprawy organizmów zmodyfikowanych genetycznie (GMO) na swoim terytorium, Dz.U. UE, L68/1, http://eur-lex.europa.eu/legal-content/PL/TXT/PDF/?uri=CELEX:32015L0412\&fro$\mathrm{m}=\mathrm{PL}$ (dostęp: 14 sierpnia 2015). 
Można zauważyć ewolucję unijnego podejścia do GMO. Oświadczenie z roku 2001 brzmiało: „stosowanie bardzo precyzyjnej technologii i szczegółowych regulacji prawnych sprawiają, że GMO jest nawet bezpieczniejsze niż konwencjonalne rośliny i żywnośćc3". Natomiast stanowisko z roku 2010 nie charakteryzuje się już taką pewnością: „Na chwilę obecną nie ma dowodów naukowych wiążących GMO z większym ryzykiem dla środowiska naturalnego, bezpieczeństwa żywności lub paszy, niż w przypadku odmian tradycyjnych" 24 . Dowodów na zachwianie ufności instytucji europejskich w proces modyfikacji genetycznych dostarcza analiza semantyczna, użycie sformułowania: „na chwilę obecną" oraz fakt, że po dziesięciu latach ryzyko związane z uprawami tradycyjnymi zostało w dokumentach zrównane z produkcją GMO.

Dnia 6 lutego 2015 r. prezydent Komorowski podpisał nowelizację ustawy z dnia 22 czerwca 2001 r. o mikroorganizmach i organizmach genetycznie zmodyfikowanych, stwierdzając:

zakaz karmienia zwierząt paszami GMO przyczyniłby się do pogorszenia konkurencyjności polskiej produkcji zwierzęcej i wzrostu cen żywności, zwłaszcza mięsa drobiowego czy wieprzowego. Byłby także nieskuteczny w zabezpieczaniu polskich konsumentów przed spożywaniem żywności pochodzącej ze zwierząt i od zwierząt karmionych paszami zawierającymi rośliny modyfikowane genetycznie ${ }^{25}$.

Ustawa po nowelizacji umożliwiła między innymi prowadzenie eksperymentalnych upraw polowych roślin transgenicznych w warunkach otwartych, a także ułatwiła import pasz GMO z innych krajów za zgodą Ministerstwa Środowiska. W ustawie zmniejszono dotychczasowe kary za uwolnienie organizmów genetycznie zmodyfikowanych do środowiska bez zezwolenia. Uprzednio za takie działanie groziła kara do 12 lat pozbawienia wolności; po zmianie uwolnienie GMO do środowiska mogło poskutkować jedynie karą pieniężną w wysokości do $200 \%$ wartości materiału siewnego. Co ważne z perspektywy przeciętnego konsumenta, producenci żywności zawierającej GMO nadal nie byli zobligowani do umieszczania żadnej informacji o zawartości GMO na etykiecie, gdy jego poziom nie przekroczył 0,9\% lub gdy produkt pochodził z chowu zwierząt karmionych paszą $\mathrm{GMO}^{26}$.

Co ważne w kontekście informowania o zawartości GMO w produktach żywnościowych, przepis nie wprowadza obowiązku informowania o tym, jakiego rodzaju modyfikacji poddane były rośliny wchodzące $\mathrm{w}$ skład produktu: czy były to jedynie zmiany aktywności genów występujących w danym organizmie, wprowadzenie do organizmu własnego dodatkowego genu czy też do czynienia mamy ze składnikiem transgenicz-

${ }^{23}$ European Commission, DG Research, EC-sponsored Research on Safety of Genetically Modified Organisms (1985-2000), 2001, http://ec.europa.eu/research/quality-of-life/gmo/, cyt. za: GBE Polska (Zielona Biotechnologia w Europie), http://www.gbepolska.pl/gbe/ (dostęp: 26 sierpnia 2015).

${ }^{24}$ European Commission, Commission publishes compendium of results of EU-funded research on genetically modified crops, 2010, http://europa.eu/rapid/press-release_IP-10-1688_en.htm (dostęp: 13 lipca 2015).

${ }^{25}$ Nowelizacja ustawy o paszach dot. GMO podpisana, www.lex.pl/czytaj/-/artykul/nowelizacja-ustawy-o-paszach-dot-gmo-podpisana (dostęp: 11 lipca 2015).

${ }^{26}$ Ustawa o mikroorganizmach i organizmach genetycznie zmodyfikowanych, z dnia 22 czerwca $2001 \mathrm{r}$., Dz.U. z 2015 r. poz. 277. 
nym. Informacja dotycząca zakresu ingerencji w produkt lub jego składnik jest kluczowa dla świadomego konsumenta.

Sytuację w Polsce radykalnie zmienić miała nowelizacja ustawy o mikroorganizmach i organizmach genetycznie zmodyfikowanych oraz niektórych innych ustaw autorstwa kolejnego rządu - Prawa i Sprawiedliwości. W zapowiedziach rozwiązania w projekcie miały na celu uczynienie z Polski jednej wielkiej strefy wolnej od upraw organizmów genetycznie modyfikowanych. Według autorów projektu nowe regulacje miały zwiększyć bezpieczeństwo ludzi i zwierząt, tworząc ochronę przed niekontrolowanym występowaniem GMO, a więc także przed wpływem takiego występowania na lokalne produkty rolne. Wprowadzone zmiany miały w zamierzeniu pozwolić na szeroką promocję polskich produktów spożywczych jako wolnych od GMO.

Tymczasem w projekcie ustawy z dnia 3 października 2016 r., art. 49a, czytamy:

1. Terytorium Rzeczypospolitej Polskiej ustanawia się strefą wolną od upraw GMO.

2. Dopuszcza się na terytorium Rzeczypospolitej Polskiej prowadzenie uprawy GMO wyłącznie na gruntach rolnych w strefie wskazanej do jej prowadzenia na określonym obszarze, zwanej dalej „strefą prowadzenia uprawy GMO", po uzyskaniu zezwolenia, o którym mowa w ust. 3. Uprawę GMO prowadzi się zgodnie z określonymi w tym zezwoleniu warunkami, sposobem i terminem.

3. Zezwolenie na utworzenie strefy prowadzenia uprawy GMO wydaje minister właściwy do spraw środowiska ${ }^{27}$.

Znowelizowana ustawa nadal zezwala na uprawę roślin genetycznie modyfikowanych na terytorium Polski.

\section{Podsumowanie}

Niezależnie od tego, jakiego rodzaju modyfikacjom genetycznym poddawany jest organizm, w opinii inżynierów genetyków mają one na celu przede wszystkim doskonalenie cech użytkowych: zwiększenie plonów, wzrost odporności na niekorzystne warunki środowiskowe, zwiększenie odporności na choroby i szkodniki, przyspieszenie konwencjonalnej produkcji oraz polepszenie właściwości roślin. Przy tym zwolennicy GMO podkreślają, iż ten rodzaj produkcji odbywa się w zgodzie z potrzebami konsumentów. Wtórna analiza badań przeprowadzona w niniejszej pracy wykazała jednak, że o ile możemy posługiwać się kategorią potrzeby w kontekście GMO, o tyle będą to potrzeby producentów.

Pomimo iż przemysł biotechnologiczny utrzymuje, że transfer genów z żywności genetycznie modyfikowanej do organizmu człowieka nie jest możliwy, to jednak badania spożycia żywności genetycznie modyfikowanej przez ludzi wykazały, iż proces ten ma miejsce. Materiał genetyczny w soi, kukurydzy czy pszenicy, który czyni je odpornymi na herbicyd, jest przenoszony do DNA ludzkich bakterii jelitowych, gdzie nadal funk-

${ }^{27}$ Projekt ustawy o mikroorganizmach i organizmach genetycznie zmodyfikowanych oraz niektórych innych ustaw z dnia 3 października 2016 r., http://legislacja.rcl.gov.pl/docs//2/12287054/12361622/1236162 3/dokument248211.pdf (dostęp: 30 października 2017). 
cjonuje. Oznacza to, że długo po tym, jak przestaniemy spożywać organizmy genetycznie modyfikowane, ich obce białka mogą być produkowane wewnątrz ludzkiego jelita ${ }^{28}$. Aktualny stan wiedzy odnośnie do wpływu spożycia organizmów modyfikowanych genetycznie na funkcjonowanie narządów wewnętrznych czy reakcje enzymów i białek oraz możliwości kumulacji tych negatywnych skutków poprzez spożycie większej ilości GMO powinny skłonić do refleksji nad zasadnością oraz faktyczną ekonomiczną i społeczną opłacalnością modyfikacji genetycznych żywności.

Wszystkie poruszone $\mathrm{w}$ artykule aspekty sprawiają, iż genetyczne modyfikacje żywności powinny być postrzegane jako kolejna, współczesna kwestia społeczna generująca wysokie koszty społeczne oraz ( $\mathrm{z}$ uwagi na ograniczony dostęp zarówno do badań, informacji na temat szkodliwości GMO, jak i coraz częściej konwencjonalnie produkowanej żywności) prowadząca do powstania zjawiska nowych nierówności w zdrowiu.

\section{Bibliografia}

Appenzeller L.M., Munley S.M., Hoban D., Sykes G.P., Malley L.A., Delaney B., Subchronic feeding study of herbicide-tolerant soybean DP-356Ø43-5 in Sprague-Dawley rats, „Food Chem Toxicol” 2008 , nr 46.

Borowicz R., Kwestie społeczne: trudne do rozwiązania czy nierozwiązywalne, Wydawnictwo Adam Marszałek, Toruń 2008.

Ervin D.E., Glenna L.L., Jussaume R.A., The theory and practice of genetically engineered crops and agricultural sustainability, „Sustainability” 2011, nr 3.

FAO, Safa Sustainability Assessment of Food and Agriculture Systems Guidelines Version 3.0; Food and Agriculture Organization: Rome, Italy, 2014.

Fischer K., Ekener-Petersen E., Rydhmer L., Edvardsson Björnberg K., Social impacts of GM crops in agriculture: A systematic literature review, „Sustainability”, 2015, nr 7.

IOCGP, Interorganizational committee on principles and guidelines for social impact assessment, principles and guidelines for social impact assessment in the USA, „Impact Assess. Proj. Apprais.” 2003, nr 21.

James C., Global Status of Commercialized Biotech/GM Crops: 2014, https://www.isaaa.org/resources/publications/briefs/49/toptenfacts/pdf/B49-Top10Facts-English.pdf.

Kosicka-Gębska M., Gębski J., Problemy rolnictwa światowego, „Zeszyty Naukowe SGGW w Warszawie” 2009, nr 9.

MacKenzie S.A., Lamb I., Schmidt J., Deege L., Morrisey M.J., Harper M., Thirteen week feeding study with transgenic maize grain containing event DAS-Ø15Ø7-1 in Sprague-Dawley rats, „Food Chem Toxicol” 2007, nr 45.

Magaña-Gómez J.A., Barca de la A.M., Risk assessment of genetically modified crops for nutrition and health, „Nutr Rev” 2009, nr 67.

Malatesta M., Boraldi F., Annovi G., Baldelli B., Battistelli S., Biggiogera M., A long-term study on female mice fed on a genetically modified soybean: effects on liver ageing, „Histochem Cell Biol” 2008, nr 130.

McNaughton J., Roberts M., Smith B., Rice D., Hinds M., Sanders C., Comparison of broiler performance when fed diets containing event DP-3Ø5423-1, nontransgenic near-isoline control, or commercial reference soybean meal, hulls, and oil, „Poult Sci” 2008, nr 87.

Netherwood T., Martín-Orúe S.M., O’Donnell A.G., Gockling S., Graham J., Mathers J.C., Gilbert H.J., Assessing the survival of transgenic plant DNA in the human gastrointestinal tract, „Nat Biotechnol” 2004, nr 22.

Pietrzyk S., Błoniarczyk K., Żywność genetycznie modyfikowana, „Biotechnologia” 2007, nr 9.

28 T. Netherwood et al., Assessing the survival of transgenic plant DNA in the human gastrointestinal tract, „Nat Biotechnol” 2004, nr 22, s. 204-209. 
Prescott V.E., Campbell P.M., Moore A., Transgenic expression of bean $r$-amylase inhibitor in peas results in altered structure and immunogenecity, „J Agric Food Chem” 2005, nr 53.

Romeis J., Dutton A., Bigler F., Bacillus thuringiences toxin (Cry $1 \mathrm{Ab}$ ) has no direct on larvae of the green lacewing Chrysoperla carnea (stephens) (Neuroptera: Chrysopidae), „J Insect Physiol” 2004, nr 50.

Smith J.M., Monsanto's Roundup Triggers Over 40 Plant Diseases and Endangers Human and Animal Health, http://www.livingnaturally.com/PDFDocs/h/HJ2WEEBJAPP58LRWP0A7VX1N09DS7D7D.PDF.

Somek A., The Social Question in a Transnational Context, LEQS Paper nr 39, Wydawnictwo London School of Economics and Political Science, London 2011.

Vendômois de J.S., Roullier F., Cellier D., Séralini G., A comparison of the effects of three GM corn varieties on mammalian health, „Int J Biol Sci” 2009, nr 5.

Verma Ch., Surabhi N., Singh R.K., Singh R.B., Sanjay M., A review on impacts of genetically modified food on human health, „The Open Nutraceuticals Journal” 2011, nr 4.

Wilson A., Latham J.R., Steinbrecher R.A., Transformation — induced mutations in transgenic plants: Analysis and biosafety implications, „Biotechnol Genet Eng” 2006, nr 23.

\section{The influence of genetic modification of food on health as a contemporary social issue}

Keywords: genetically modified food, health status, social issue, GMOs in the EU and Poland

\section{Summary}

The article attempts to demonstrate that the process of genetic modification of food and its consequences in the form of influencing the health of entire societies, agro-ecosystems and the environment, which increasingly depends on the degree to which basic needs are met, is a contemporary social issue. Based on the results of mainly biochemical and biotechnological research, the types of genetic modifications of food and their impact on health have been analysed. Secondary analysis of the studies allowed the identification of multi-organ dysfunction syndrome of laboratory animals in reaction to the consumption of genetically modified plants. The paper also analyses the documents of the European Union and the Polish legislation concerning the admission to cultivation and subsequent trade of food products containing genetically modified ingredients. 